\title{
Agitococcus lubricus gen. nov. sp. nov., a Lipolytic, Twitching Coccus from Freshwater
}

\author{
P. D. FRANZMANN* AND V. B. D. SKERMAN \\ Department of Microbiology, University of Queensland, St. Lucia 4067, Brisbane, Australia \\ Three strains of a gram-negative coccus which exhibits twitching motility and \\ which grows in a monolayer of cells on non-lipid-containing media were isolated \\ from freshwater. A new genus, Agitococcus, with a single species, $A$. lubricus sp. \\ nov., is proposed for these strains. The type strain of this species is UQM 1981.
}

During an investigation of the microflora of Queensland freshwater deposits, 18 strains of a coccus producing a monolayer of cells on lake water agar (LWA) and exhibiting twitching motility were isolated. The morphology and distribution of cells in the spreading microcolonies closely resembled those of the cells featured by Winogradsky for Nitrosococcus nitrosus (20), but these strains proved to be unrelated to it. The deoxyribonucleic acid (DNA) base ratios of some of these strains are considerably different. Three strains with essentially identical DNA base ratios have been fully characterized and are herewith described as belonging to a new genus and species. Studies on the other strains are continuing.

\section{MATERIALS AND METHODS}

Bacterial strains. The strains of bacteria used in this study are listed in Table 1.

Media. All media were sterilized by autoclaving at $121^{\circ} \mathrm{C}$ for $15 \mathrm{~min}$. (i) For LWA, lake water was filtered through a $2.0-\mu \mathrm{m}$ Sartorius membrane filter to remove optically visible particles. The medium was solidified with 1.5\% agar (Difco). (ii) For lake water-Noble agar, filtered lake water was solidified with $1.5 \%$ Noble agar (Difco). The pH (6.8) was not adjusted. (iii) Lake water-peptone-yeast extract agar consisted of: LWA, 1,000.0 ml; yeast extract (Difco), $0.1 \mathrm{~g}$; and Peptone (Difco), 0.1 g. (iv) Casitone-yeast extract broth (CYEB) contained: Casitone (Difco), $5.0 \mathrm{~g}$; yeast extract (Difco) $3.0 \mathrm{~g} ; \mathrm{MgSO}_{4} \cdot 7 \mathrm{H}_{2} \mathrm{O}, 2.0 \mathrm{~g}$; and distilled water, $1,000.0 \mathrm{ml} ; \mathrm{pH}$ adjusted to 7.2 . (v) Casitoneyeast extract agar (CYEA) contained: CYEB, 1,000.0 $\mathrm{ml}$; and agar (Difco), $15.0 \mathrm{~g}$. (vi) Tween 80 broth consisted of: CYEB, $1,000.0 \mathrm{ml}$; and Tween $80,10.0 \mathrm{ml}$. (vii) Tween 80 agar (T80A) contained: Tween 80 broth $1,000.0 \mathrm{ml}$; and agar (Difco), $15.0 \mathrm{~g}$. (viii) For lecithin agar, a sterilized lecithin emulsion was added to slightly concentrated CYEA modified to yield a medium in which the final concentration of ingredients after addition of lecithin was the same as normal CYEA. (a) To prepare lecithin emulsion, $2.5 \mathrm{~g}$ of lecithin was added to $75.0 \mathrm{ml}$ of distilled water, the $\mathrm{pH}$ was adjusted to 7.2 , and the emulsion was sterilized at $121^{\circ} \mathrm{C}$ for $15 \mathrm{~min}$. (b) modified CYEA consisted of: Casitone (Difco), $5.0 \mathrm{~g}$; yeast extract (Difco), $3.0 \mathrm{~g}$; $\mathrm{MgSO}_{4} \cdot 7 \mathrm{H}_{2} \mathrm{O}, 2.0 \mathrm{~g}$; distilled water, $850.0 \mathrm{ml}$; and agar
(Difco), $15.0 \mathrm{~g} ; \mathrm{pH}$ adjusted to 7.2 . To $425.0 \mathrm{ml}$ of modified CYEA, $75.0 \mathrm{ml}$ of lecithin emulsion was added to produce lecithin agar.

Isolation procedure. The original isolates were obtained from surface waters of the littoral zone of University Lake, Brisbane, Australia. Single drops of water samples were allowed to flow across the surface of LWA. Excess moisture was evaporated from the surface at $22^{\circ} \mathrm{C}$ in a sterile atmosphere. Plates were incubated and examined periodically with a Leitz PHACO $32 \times$ phase-contrast objective. Typical microcolonies normally appeared within $14 \mathrm{~h}$ and were selected with a microloop with equipment and methods described by Skerman (14). Microcolonies formed from isolated cells were transferred to lake waterpeptone-yeast extract agar and later transferred to T80A.

Photography. A sterile slide was placed on the surface of an LWA plate. Over this slide $7.0 \mathrm{ml}$ of LWA was poured and allowed to set; a layer of medium $0.7 \mathrm{~mm}$ thick was thus produced on the surface of the glass. The agar above the slide was inoculated by flowing a drop of cell suspension along the surface. The plate was dried at $22^{\circ} \mathrm{C}$ in a sterile atmosphere. After incubation of the plates for $19 \mathrm{~h}$, the slide was excised from the plate, and the microcolonies were covered with a clean cover glass and photographed under a phase-contrast objective (100X) with an Olympus PM-6 camera attachment and EMM-6 exposure meter. Kodak Plus-X Pan film and a green filter were used.

Cellular morphology and staining reactions. Cell size was determined from photographs of microcolonies. Impressions of microcolonies were stained by the Bartholomew method (13) for the Gram stain. Strains grown on $\mathrm{T} 80 \mathrm{~A}$ for $24 \mathrm{~h}$ at $28^{\circ} \mathrm{C}$ were examined for capsules by dry Indian ink film methods (4) and for sudanophilic inclusions by Sudan black B stain (4). Evidence for twitching movement was sought first on uncovered microcolonies with the aid of the Leitz PHACO $32 \times$ phase-contrast objective and then by examination of a thin film of liquid formed by placing a drop of sterile distilled water on the microcolony and compressing it under a sterile cover glass. Evidence of other forms of motility were sought in a hanging drop of a Tween 80 broth culture incubated at $28^{\circ} \mathrm{C}$ for 24 h.

Electron microscopy. All specimens were examined with a Philips EM 300 transmission electron microscope. Cells of all strains were examined after 
TABLE 1. List of strains used in this study

\begin{tabular}{|c|c|c|c|c|}
\hline \multirow{2}{*}{ Collection no. } & \multicolumn{2}{|c|}{ Received as: } & \multirow{2}{*}{ Source $^{a}$} & \multirow{2}{*}{ Habitat } \\
\hline & Name & Strain & & \\
\hline UQM 566 & Staphylococcus aureus & NCTC 6571 & (1) & $?$ \\
\hline UQM 848 & Escherichia coli & NCTC 10418 & (1) & $?$ \\
\hline UQM 1803 & Escherichia coli & ATCC 11775 & (2) & $?$ \\
\hline UQM 1981 & Original isolate & & & Freshwater \\
\hline UQM 1982 & Original isolate & & & Freshwater \\
\hline UQM 1983 & Original isoalte & & & Freshwater \\
\hline
\end{tabular}

a (1) NCTC, National Collection of Type Cultures, London, England; (2) ATCC, American Type Culture Collection, Rockville, Md. 20852; UQM, Department of Microbiology, University of Queensland, St. Lucia, 4067, Queensland, Australia (the Australian National Collection of Bacteria).

negative staining with $1.0 \%$ phosphotungstic acid for $20 \mathrm{~s}$. To search for flagella, colonies of actively twitching cells, grown on LWA for $24 \mathrm{~h}$ at $28^{\circ} \mathrm{C}$, were covered with $0.1 \mathrm{ml}$ of sterile distilled water. A nitrocellulosecoated copper grid was supported on 0.10 - to $0.11-\mathrm{mm}$ diameter sterile glass beads above the colonies. After $1 \mathrm{~h}$ of incubation at $22^{\circ} \mathrm{C}$, cells showed twitching motility on the nitrocellulose film surface. The cells were fixed with $1.0 \%$ osmium tetroxide in $0.2 \mathrm{M}$ cacodylate buffer, pH 7.0, for $10 \mathrm{~min}$. The grid was washed in distilled water, blotted dry, negatively stained, and examined. For the preparation of thin sections strain UQM 1981 was grown for $24 \mathrm{~h}$ in $\mathrm{T} 80 \mathrm{~A}$ at $28^{\circ} \mathrm{C}$, fixed by the ruthenium red method of Luft (9), and embedded in Epon 812 epoxy resin. Sections were cut on a Reichert microtome OMU 2. Sections were stained in $4.0 \%$ uranyl acetate for $30 \mathrm{~min}$ and for $2 \mathrm{~min}$ in $1.2 \%$ lead citrate. Strains were critical-point dried by the method of Cagle (2) to demonstrate capsular polymer strands.

Colony morphology. Colony morphology was recorded on CYEA and T80A after growth at $28^{\circ} \mathrm{C}$ for $48 \mathrm{~h}$.

Biochemical and physiological tests. All test media were inoculated from 24 -h-old growth of each strain on T80A at $28^{\circ} \mathrm{C}$. All test cultures, unless otherwise stated, were incubated at $28^{\circ} \mathrm{C}$. Media cited by Skerman (13) were used for the following tests: growth in autotrophic medium for Nitrosomonas after 7 days; growth in $\mathrm{N}$-free medium after 7 days; deposition of iron; hemolysis of horse blood after 7 days; urease; and serum liquefaction.

Growth on T80A for $24 \mathrm{~h}$ was used to test for catalase and benzidine production (13). Gelatin hydrolysis was tested in Tween 80 broth with $25.0 \%$ gelatin incubated at $22^{\circ} \mathrm{C}$ for 31 days (13). Medium T80A was used as the basal medium for hydrolysis, after 14 days, of cellulose, starch, and alginate (13). The production of $\mathrm{H}_{2} \mathrm{~S}$ after 14 days was detected with lead acetate paper strips suspended over the peptonecystine sulfate medium (13) supplemented with $1.0 \%$ Tween 80 . Blood agar (13) heated at $75^{\circ} \mathrm{C}$ until it became chocolate brown was used to test decolorization of chocolate agar. The plates were inoculated and inspected after 7 days of incubation. Lecithin hydrolysis was tested on lecithin agar, which was inoculated and incubated for 7 days. A zone of opalescence around the colony indicated lecithin hydrolysis.

Other tests performed were the following: oxidation or fermentation of glucose (7); oxidase in cells grown on T80A for $24 \mathrm{~h}$ (17); indole production (1); L-tryptophane and L-phenylalanine deamination (1); nitrate reduction and reaction in triple sugar iron agar, both including $5.0 \%$ horse serum in the medium (1); proteolysis of skim milk and susceptibility to $0.1 \%$ sodium lauryl sulfate in media supplemented with $1.0 \%$ Tween 80 (1); and tributyrin hydrolysis (19). Hydrolysis of Tween 80 was tested on T80A with incubation for 6 days. Tween 40 and Tween 20 hydrolyses were tested in the same way but by substitution of Tween 40 and Tween 20 for the Tween 80 (12). The test for deoxyribonuclease (8) was performed on deoxyribonuclease agar (Oxoid) supplemented with $1.0 \%$ Tween 80. Growth at different temperatures was tested on slants of T80A at $4,15,25,28,37,41$, and $45^{\circ} \mathrm{C}$; slants were examined after 7 days. Growth in the presence of different salt concentrations was tested on T80A supplemented with $0.1,0.5,1.0$, and $2.0 \% \mathrm{NaCl}$. Plates were inoculated and, after $48 \mathrm{~h}$, were examined for growth. Growth at various pH's was tested on CYEA aseptically adjusted to the desired $\mathrm{pH}$ with sterile 1.0 $\mathrm{M} \mathrm{HCl}$ or $1.0 \mathrm{M} \mathrm{NaOH}$ after sterilization. Plates were inoculated and, after $48 \mathrm{~h}$ of incubation, were examined for microcolony formation. For anaerobic growth determinations, inoculated CYEA cultures were incubated for $48 \mathrm{~h}$ in a gas jar with an atmosphere of $10 \%$ $\mathrm{CO}_{2}-90 \% \mathrm{H}_{2}$. Utilization of sodium acetate, sodium propionate, and glycerol was tested by the carbon utilization test methods and the mineral media of Stanier et al. (15).

Susceptibility to antibiotics. Disks produced by Mast Laboratories Ltd., Liverpool, England, were laid on T80A plates which had been surface inoculated with the test strains (5) and also with Staphylococcus aureus UQM 556 and Escherichia coli UQM 848 as standards for antibiotic susceptibility (18). The disks used were: penicillin $\mathrm{G}, 4 \mathrm{U}$; chloramphenicol $25 \mu \mathrm{g}$; tetracycline, $10 \mu \mathrm{g}$; erythromycin, $5 \mu \mathrm{g}$; streptomycin, $10 \mu \mathrm{g}$; kanamycin, $30 \mu \mathrm{g}$; and neomycin, $10 \mu \mathrm{g}$. Where a test strain was shown to be moderately susceptible to an antibiotic, the test strain and the relevant control organism were checked again but on the same instead of different plates.

Determination of DNA base composition. DNA was isolated by the method of Marmur (10). DNA melting curves were obtained for DNA in $0.1 \times \mathrm{SSC}$ ( $\mathrm{SSC}=0.15 \mathrm{M} \mathrm{NaCl}$ plus $0.015 \mathrm{M}$ trisodium citrate) on a Guilford automatic recording spectrophotometer 
TABLE 2. Morphological, biochemical, and physiological characters of A. lubricus gen. nov. sp. nov. ${ }^{a}$

\begin{tabular}{|c|c|c|c|}
\hline Character/test & Reaction & Character/test & Reaction \\
\hline Cell Shapes & Coccus & Lecithinase & + \\
\hline Cell diameter $(\mu \mathrm{m})$ & $1.0-2.0$ & Tributyrin hydrolysis & - \\
\hline Capsule present & + & Starch hydrolysis & - \\
\hline Sudanophilic inclusions & + & Cellulose hydrolysis & - \\
\hline Twitching motility & + & Alginate hydrolysis & - \\
\hline $\mathrm{G}+\mathrm{C}$ of DNA (mol\%) & $42.4 \pm 1.0$ & Growth at: & \\
\hline Oxidase & + & $4^{\circ} \mathrm{C}$ & - \\
\hline Catalase & - & $15^{\circ} \mathrm{C}$ & + \\
\hline Benzidine & + & $37^{\circ} \mathrm{C}$ & + \\
\hline Acid from glucose $(\mathrm{O} / \mathrm{F})^{b}$ & - & $41^{\circ} \mathrm{C}$ & - \\
\hline Anaerobic growth & - & Growth on $0.1 \%$ sodium lauryl sulfate & + \\
\hline Acid in TSI $^{c}$ & - & Growth at $\mathrm{pH}$ : & \\
\hline $\mathrm{H}_{2} \mathrm{~S}$ production (lead acetate) & - & 5.0 & - \\
\hline $\mathrm{H}_{2} \mathrm{~S}$ in TSI & - & 6.0 & + \\
\hline Deamination of tryptophane & - & 10.0 & + \\
\hline Deamination of phenylalanine & - & Growth on $\mathrm{NaCl}$ : & \\
\hline Indole production & - & $0.1 \%$ & + \\
\hline Nitrate reduction & - & $0.5 \%$ & + \\
\hline Urease & - & $1.0 \%$ & - \\
\hline Growth in $\mathrm{N}$-free medium & - & Susceptibility to: & \\
\hline Growth on Nitrosomonas sp. medium & - & Penicillin G & + \\
\hline Gelatin hydrolysis & - & Chloramphenicol & + \\
\hline Proteolysis of skim milk & + & Tetracycline & + \\
\hline Serum liquefaction & - & Erythromycin & + \\
\hline Hemolysis & - & Streptomycin & + \\
\hline Decolorization of chocolate agar & - & Kanamycin & + \\
\hline Deposition of iron & - & Neomycin & + \\
\hline Tween 8 hydrolysis & + & Utilization of: & \\
\hline Tween 40 hydrolysis & + & Acetate & - \\
\hline \multirow[t]{2}{*}{ Tween 20 hydrolysis } & + & Propionate & - \\
\hline & & Glycerol & - \\
\hline
\end{tabular}

${ }^{a}$ Symbols: +, Positive; -, negative.

${ }^{b} \mathrm{O} / \mathrm{F}$, Oxidation/fermentation.

${ }^{c}$ TSI, Triple sugar iron.

2400 , and from these the melting temperatures were determined (11). E. coli UQM 1803 DNA, with 51.7 $\mathrm{mol} \%$ guanine plus cytosine $(\mathrm{G}+\mathrm{C})(16)$, was used as the internal standard. The $\mathrm{G}+\mathrm{C}$ content (as moles percent) was determined for each strain by means of a rearranged equation of Marmur and Doty (11): moles percent $(\mathrm{G}+\mathrm{C})_{x}=$ moles percent $(\mathrm{G}+\mathrm{C})_{\text {std }}+2.44$ $\left(T_{m_{x}}-T_{m_{\text {std }}}\right)$, where std refers to the DNA of the standard, $x$ refers to the DNA of the test organism, and $T_{m}$ is the melting temperature. Determinations on each strain were done in triplicate.

Stimulation of growth by Tween 80. A 24-h-old growth of T80A was suspended in sterile distilled water to a density of $10^{8}$ cells per $\mathrm{ml}$ for use as inoculum. To side-arm flasks containing $100 \mathrm{ml}$ of CYEB, CYEB plus $1.0 \%$ Tween 80 or CYEB plus $1.0 \%$ filter-sterilized glucose, 5-ml amounts of inoculum were added. Flasks were incubated in an incubator shaker at $28^{\circ} \mathrm{C}$. Density readings were taken over 24 h against a blank of CYEB (see Fig. 5).

\section{RESULTS}

The DNA base ratios of strains UQM 1981, UQM 1982, and UQM 1983 were $42.7 \pm 1.6,42.7$ \pm 0.7 , and $42.1 \pm 0.3 \mathrm{~mol} \%$, respectively, based on three analyses for each strain.

Morphologically, biochemically, and physio- logically, the three strains were identical (Table 2).

The distribution of cells in a young microcolony on LWA is shown in Fig. 1 and 2. Thin sections of cells are shown in Fig. 3, and cells from LWA subjected to critical-point drying are shown in Fig. 4. Actively twitching cells that were fixed and negatively stained showed no evidence of flagellation.

Colonies of all strains on CYEA were 2.0 to $3.0 \mathrm{~mm}$ in diameter, erose, flat, transparent, glistening, smooth, and butyrous; on T80A, the colonies were 2.0 to $3.0 \mathrm{~mm}$ in diameter, entire, low convex to umbonate, opaque, glistening, smooth, and butyrous. (UQM 1981 was mucoid.)

No measurable growth of any strain was produced in CYEB and CYEB plus 1.0\% glucose. The amount of growth produced on CYEB plus $1.0 \%$ Tween 80 by each strain is graphically illustrated by a sigmoid curve (e.g., see Fig. 5).

\section{DISCUSSION}

Cells of Agitococcus lubricus are coccoid, but larger, distended forms occur when the cells are 
filled with sudanophilic inclusions; the development of these forms is more pronounced in aging cells of T80A than on LWA. In Fig. 2, a cell in the center of a microcolony (Fig. 2) shows the early appearance of these granules, which are found in most cells in old culture. Thin sections (Fig. 3) show large white areas once occupied by sudanophilic inclusions. Some bleblike evaginations of the cell wall are visible. The cell wall is characteristic of a gram-negative cell. Criticalpoint-dried preparations (Fig. 4) show strands of extracellular capsule polymer.

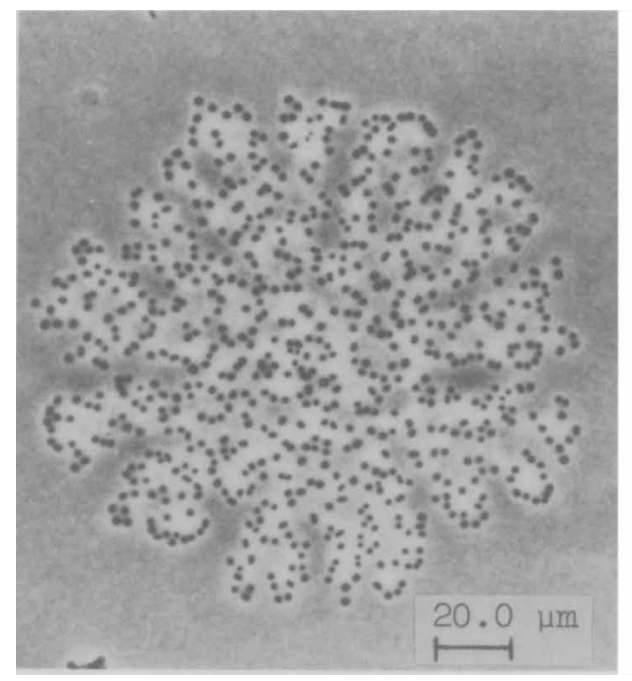

Fig. 1. A. lubricus strain on an isolation plate of $L W A$ after incubation for $21 \mathrm{~h}$ at $22^{\circ} \mathrm{C}$.
Twitching motility occurs on T80A and LWA surfaces, but it is more pronounced when the cells are sandwiched between a cover glass and the agar surface film.

The migration of cells on a solid agar surface is shown in the microcolony form on LWA (Fig. 1), where the areas of the agar traversed by the migrating cells appear white against the gray background, characteristic of the slime trails of gliding bacteria. Occasionally, single cells migrate away from the edge of the colony. Migration is active on LWA and on CYEA but not on

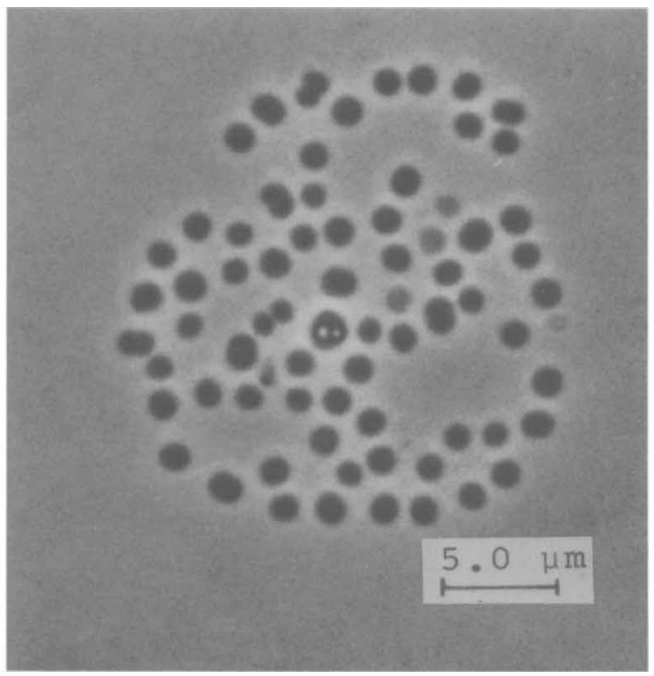

FIG. 2. A. lubricus strain UQM 1981 grown for 19 $h$ on lake water-Noble agar at $28^{\circ} \mathrm{C}$.

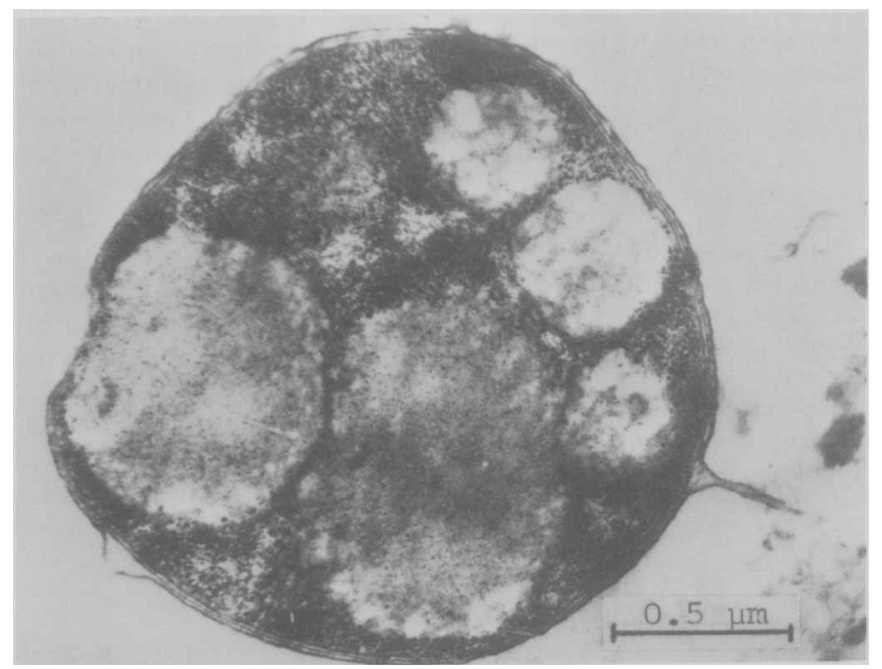

FIG. 3. Thin section of A. lubricus strain UQM 1981 grown for $24 h$ on T80A. 
media supplemented with metabolizable Tween 80. Although this suggests that there may be a relationship to the availability of metabolizable substrate (Fig. 5), twitching is still very active on the Tween 80 media so that restriction on migration is more likely to be due to a surface tension effect. On media containing Tween 80, the twitching does not seem to serve any specific

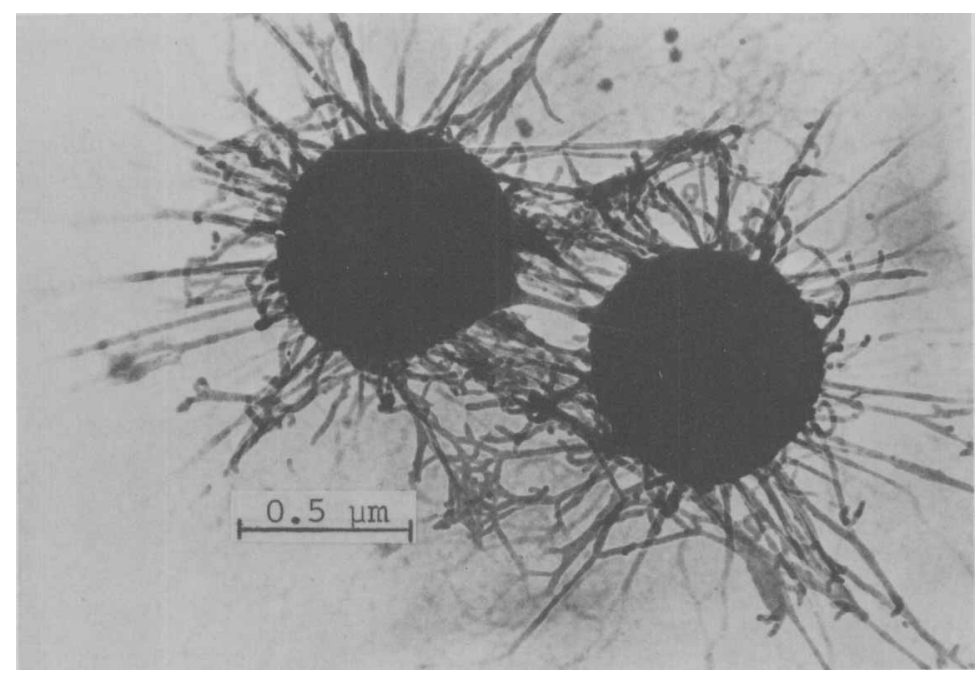

FIG. 4. Critical-point-dried preparation of A. lubricus strain UQM 1982 grown for 24 h on LWA at $28^{\circ} \mathrm{C}$.

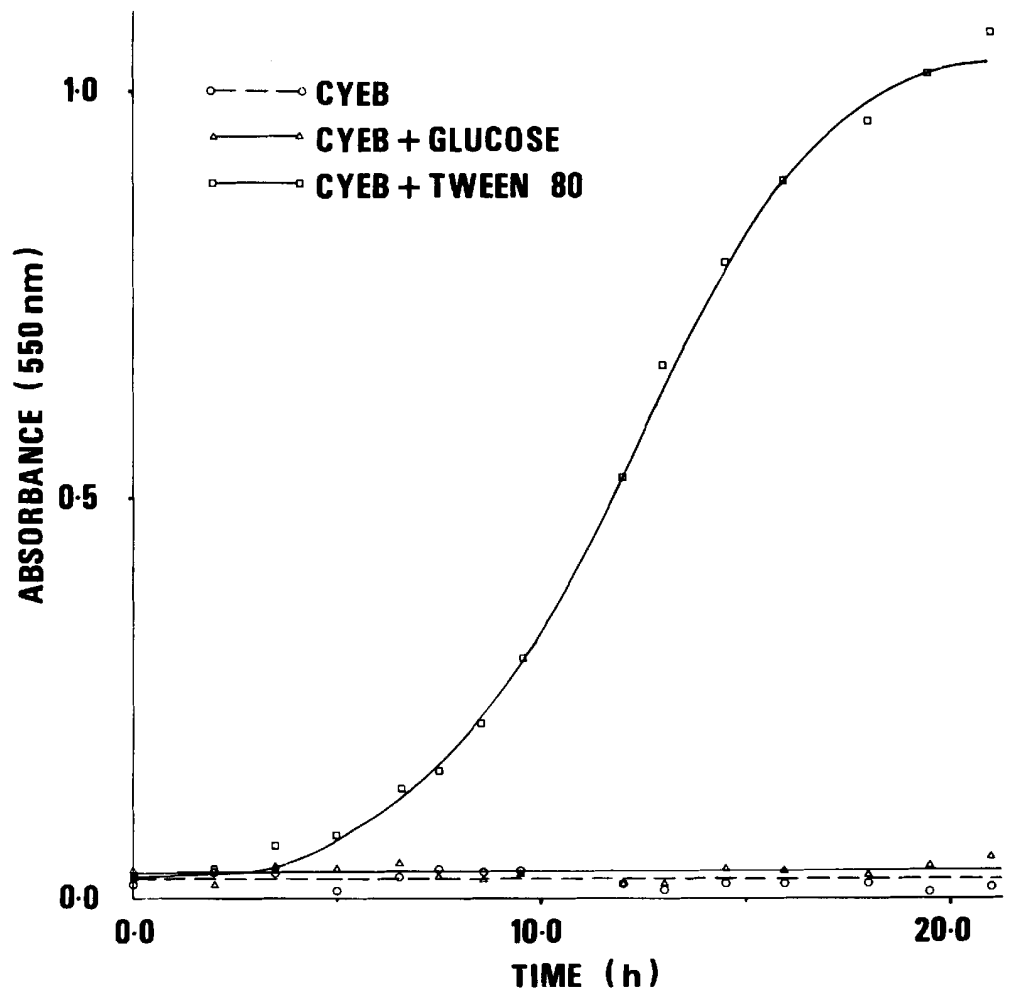

FIG. 5. Growth of A. lubricus strain UQM 1981 in $100 \mathrm{ml}$ of CYEB, CYEB plus $1.0 \%$ glucose, and CYEB plus $1.0 \%$ Tween 80 incubated at $28^{\circ} \mathrm{C}$. 
purpose; colonies develop in a manner similar to that of most other bacteria. In the process of primary isolation of another strain not included in this report, it was noted that on LWA coated with immiscible paraffin oil, microcolonies in and immediately adjacent to the oil droplets showed cells in close approximation, whereas microcolonies well separated from the oil showed the migratory pattern of Fig. 1.

Although in the spreading microcolony the organisms described in this paper bore a striking resemblance to those featured by Winogradsky (20) for $N$. nitrosus, they showed no evidence of autotrophic growth in an ammonium sulfate mineral salts medium for Nitrosomonas and, in fact, show a great affinity for fats or fatty acid derivatives. The active twitching form of motility resembles that of the Moraxella-Acinetobacter group, but the cocci are larger and show little affinity to these genera. Also, there is no evidence of fimbriae of the kind reported to be implicated in the movement of cells of the foregoing group (6). In consequence of this, a new genus with a single species is proposed. This species is represented by only three strains isolated on different occasions from the same habitat. Fifteen other strains currently under investigation have the same morphological and cultural characteristics as the three strains reported here, but some differ considerably in their DNA base contents. These will be the subject of later communications.

Agitococcus gen. nov. (L. v. agito to shake; $\mathrm{Gr}$. n. coccus a grain or berry; M.L. masc. n. Agitococcus shaking coccus) is described as follows: gram-negative cocci, 1.0 to $2.0 \mu \mathrm{m}$ in diameter, which distend with sudanophilic inclusions in old cultures. Twitching motility. No flagella are present. Capsules are present. Glucose is neither oxidized nor fermented. Growth is stimulated by Tween 80 . Aerobic. Oxidase positive. Catalase negative. Tween 80 , Tween 40 , and Tween 20 are hydrolyzed. Lecithinase is produced. Tributyrin, starch, cellulose, and alginate are not hydrolyzed. Nitrate is not reduced. $\mathrm{H}_{2} \mathrm{~S}$ is not produced. Indole is not produced. Gelatin is not hydrolyzed. Serum is not liquefied. Proteolysis of skim milk is positive. Hemolysis of horse blood erythrocytes is negative. Decolorization of chocolate agar is negative. Tryptophane and phenylalanine are not deaminated. Urease is negative. Growth occurs at 15 and $37^{\circ} \mathrm{C}$ but not at 4 or $41^{\circ} \mathrm{C}$. Growth occurs at $\mathrm{pH} 6.0$ and 10.0 but not at $\mathrm{pH} 5.0$. No growth occurs in the presence of $1.0 \%$ sodium chloride, but growth occurs with $0.5 \%$ sodium chloride. Grows on $0.1 \%$ sodium lauryl sulfate. Susceptible to antibiotics (penicillin $\mathrm{G}, 4 \mathrm{U}$; chlorampheni- col, $25 \mu \mathrm{g}$; tetracycline, $10 \mu \mathrm{g}$; kanamycin, $30 \mu \mathrm{g}$; neomycin, $10 \mu \mathrm{g}$; erythromycin, $5 \mu \mathrm{g}$; and streptomycin, $10 \mu \mathrm{g}$ ). The $\mathrm{G}+\mathrm{C}$ content of the DNA is $42.2 \pm 1.0 \mathrm{~mol} \%$.

Type species: Agitococcus lubricus sp. nov. (L. adj. lubricus slippery).

Description of $A$. lubricus: same as for the genus.

Type strain: UQM 1981.

The ecological role of $A$. lubricus appears to be the degradation of lipids in freshwater bodies or in the lipid films on the surfaces of freshwater.

\section{ACKNOWLEDGMENTS}

We thank Jane Westcott and Tony McGregor for assistance with the electron microscopy.

\section{LITERATURE CITED}

1. Bøvre, K., and S. D. Henriksen. 1976. Minimal standards for description of new taxa within the genera Moraxella and Acinetobacter: proposal by the Subcommittee on Moraxella and Allied Bacteria. Int. J. Syst. Bacteriol. 26:92-96.

2. Cagle, G. D. 1974. Critical-point drying: rapid method for the determination of bacterial extracellular polymer and surface structures. Appl. Microbiol. 28:312-316.

3. Christensen, P. J., and F. D. Cook. 1972. The isolation and enumeration of cytophagas. Can. J. Microbiol. 18: 1933-1940.

4. Cruickshank R., J. P. Duguid, B. P. Marmion, and R. H. A. Swain. 1975. Staining methods, p. 43-45. In Medical microbiology, vol. 2. The practice of medical microbiology, 12th ed. Churchill Livingstone Edinburgh.

5. Cruickshank, R., J. P. Duguid, B. P. Marmion, and R. H. A. Swain. 1975. Tests for sensitivity to antimicrobial agents, p. 196-197. In Medical microbiology, vol. 2. The practice of medical microbiology, 12th ed. Churchill Livingstone, Edinburgh.

6. Henrichsen, J. 1975. On twitching motility and its mechanism. Acta Pathol Microbiol. Scand. Sect. B. 83:187190.

7. Hugh, R., and E. Leifson. 1953. The taxonomic significance of fermentative versus oxidative metabolism of carbohydrates by various gram-negative bacteria. J. Bacteriol. 66:24-26.

8. Jeffries, C. D., D. F. Holtman, and D. G. Guse. 1957. Rapid method for determining the activity of microorganisms on nucleic acids. J. Bacteriol. 73:590-591.

9. Luft, J. H. 1971. Ruthenium red and violet. I. Chemistry, purification, methods of use for electron microscopy and mechanism of action. Anat. Rec. 171:347-368.

10. Marmur, J. 1961. A procedure for the isolation of deoxyribonucleic acid from microorganisms. J. Mol. Biol. 3: 208-218.

11. Marmur, J., and P. Doty 1962. Determination of base composition of deoxyribonucleic acid from its thermal denaturation temperature. J. Mol. Biol. 5:109-118.

12. Sierra, G. 1957. A simple method for the detection of lypolytic activity of microorganisms and some observations on the influence of the contact between cells and fatty substrates. Antonie van Leeuwenhoek J. Microbiol. Serol. 23:15-22.

13. Skerman, V. B. D. 1967. A guide to the identification of the genera of bacteria, 2 nd ed. The Williams $\&$ Wilkins Co., Baltimore.

14. Skerman, V. B. D. 1968. A new type of micromanipulator. 
J. Gen. Microbiol. 54:287-298.

15. Stanier, R. Y., N. J. Palleroni, and M. Doudoroff. 1966. The aerobic pseudomonads: a taxonomic study. J. Gen. Microbiol. 43:159-271.

16. Starr, M. P., and M. Mandel. 1968. DNA base composition and taxonomy of phytopathogenic and other enterobacteria. J. Gen. Microbiol. 56:113-123.

17. Steel, K. J. 1962. The oxidase activity of staphylococci. J. Appl. Bacteriol. 25:445-447.
18. The Public Health Laboratory Service Board. 1972. Antibiotic, disinfectant and sterilization test strains, $p$. 283-285. In Catalogue of the National Collection of Type Cultures, 5th ed. Her Majesty's Stationery Office, London.

19. Willis, A. T. 1960. The lipolytic activity of some clostridia. J. Pathol. Bacteriol. 80:379-390.

20. Winogradsky, S. 1949. Microbiologie du sol. Masson et Cie, Éditeurs, Paris. 